\title{
On the Composition and Age of Taphofloras of the Krivorechenskaya Formation (Upper Cretaceous) of the Anadyr River Left Bank, Northeast Asia
}

\author{
A. B. Herman ${ }^{a, *}$ and S. V. Shczepetov ${ }^{b, * *}$ \\ ${ }^{a}$ Geological Institute, Russian Academy of Sciences, Moscow, Russia \\ ${ }^{b}$ Komarov Botanical Institute, Russian Academy of Sciences, St. Petersburg, Russia \\ *e-mail: alexeiherman@yandex.ru \\ **e-mail:shchepetov@mail.ru
}

Received December 29, 2020; revised February 1, 2021; accepted February 8, 2021

\begin{abstract}
Chineiveem taphoflora from the Krivorechenskaya Formation of the Anadyr River left bank (Northeast Asia) is characterized by a relatively low diversity of plants represented by ginkgoaleans, conifers, and angiosperms. Judging by their systematic composition, this taphoflora is younger than the Grebenka flora from the Krivorechenskaya Formation of the Anadyr River basin. Its closest analog is the Penzhina flora of Northwestern Kamchatka and the Yelistratov Peninsula, the age of which is reliably defined as Turonian, excluding the beginning of the Turonian. Therefore, the age of the Chineiveem floristic assemblage is also Turonian, most probably late Turonian. Such dating of this taphoflora is in agreement with the late Turonian or Coniacian age of marine mollusks from the overlying Dugovskaya Formation layers of the Chineiveem River and with a conformable stratigraphic contact of these layers with the plant-bearing beds. A tectonic contact between these deposits is not supported by our paleobotanical data. The observed succession of taphofloras from the Krivorechenskaya Formation in the Ubiyenka-Chineiveem interfluve suggests that the upper age limit of the Grebenka flora is the beginning of the Turonian.
\end{abstract}

Keywords: Northeast Asia, plant megafossils, floristic assemblage, inoceramids, paleofloristics, stratigraphy, Albian, Cenomanian, Turonian

DOI: $10.1134 / \mathrm{S} 0869593821050051$

\section{INTRODUCTION}

The part of the Eurasian continent east of the Lena River is commonly referred to as Northeast Asia (Samylina, 1974). Upper Mesozoic deposits of various origin are widely represented here. According to the character of sedimentation during the Cretaceous, this territory is divided into three subregions (Herman, 1993, 2011) or regions (Resheniya..., 2009). The Anadyr-Koryak subregion (Fig. 1) is characterized by alternation of Cretaceous deposits of marine and continental genesis across sections and/or along the strike; the latter, being formed mainly in the conditions of coastal lowlands and plains, contain abundant and diverse plant fossils. Fossil mollusks and foraminifera from marine layers allow the plant remains from nonmarine sediments to be securely dated (Herman, 2011).

This feature makes some sections of the AnadyrKoryak subregion essential for the development of stratigraphic schemes of the nonmarine AlbianUpper Cretaceous of Northeast Russia. At the same time, the fossil floras considered as phytostratigraphic references characterize certain evolution stages of ancient flora over a large territory; each of these floras includes individual taphofloras, or paleofloristic assemblages, which, in turn, include plants from one or several geographically and stratigraphically close localities (Herman, 2011). For the first half of the Late Cretaceous, the Grebenka (late Albian-early Turonian), Penzhina (Turonian, excluding its beginning), and Kaivayam (Coniacian) evolutionary stages of the ancient flora were distinguished and described (Herman, 2011; Herman and Lebedev, 1991; Filippova and Abramova, 1993; Samylina, 1974; Shczepetov et al., 1992; Spicer et al., 2002).

Grebenka flora from the Krivorechenskaya Formation in the middle reaches of the Anadyr River is the richest and most diverse of the Late Cretaceous floras of Northeast Asia. It is one of the most important phytostratigraphic correlation references of the regional nonmarine Cretaceous. The Grebenka stage, opening the Late Cretaceous florogenesis in northeastern Russia, was identified by Samylina (1974). The Grebenka flora of the middle reaches of the Anadyr River and the Middle Ginter flora of Ugolnaya Bay were formed during this stage (Herman, 2011; Moise- 


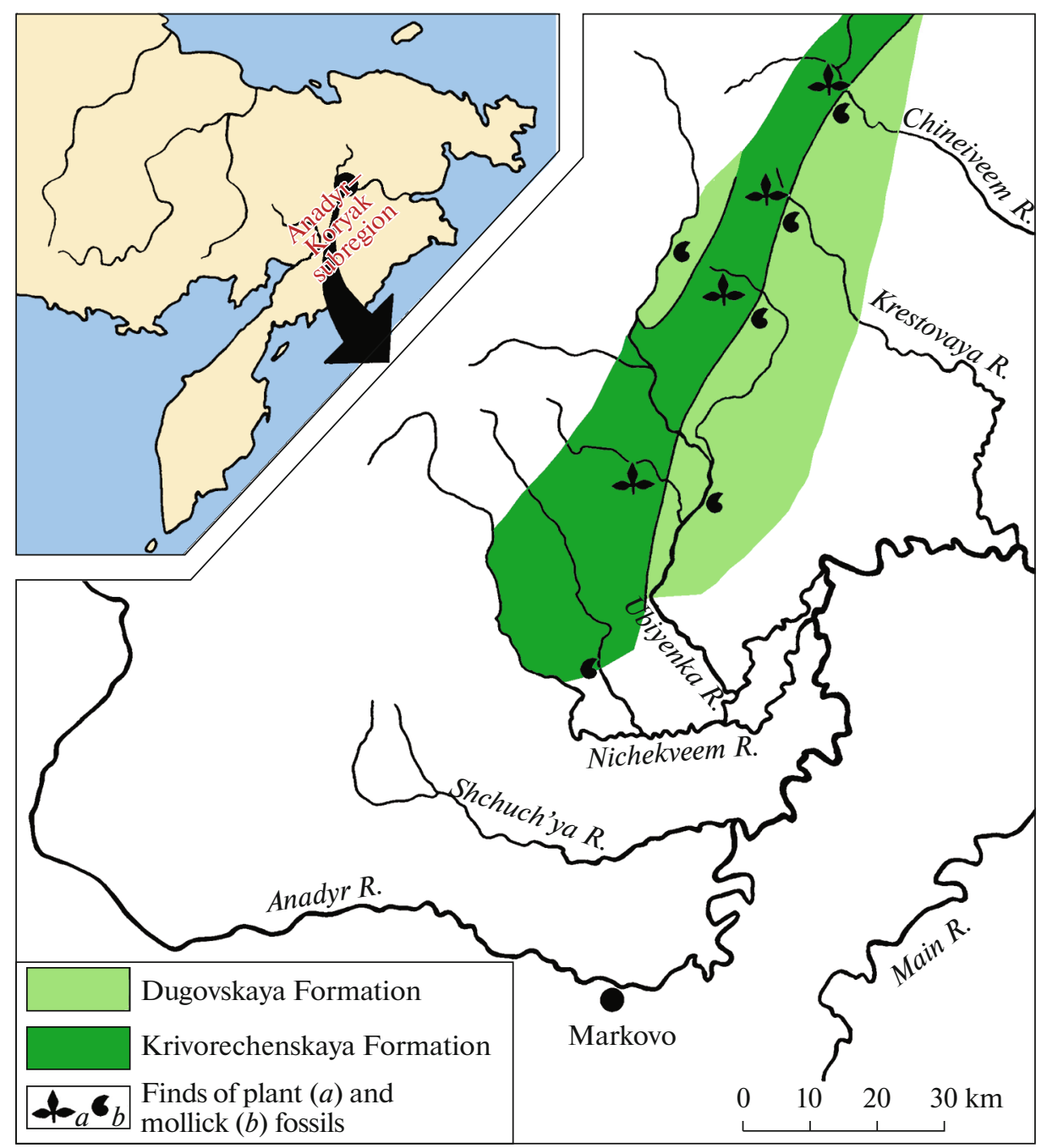

Fig. 1. Distribution of plant-bearing deposits of the Krivorechenskaya Formation and overlying Dugovskaya Formations on the left bank of the middle reaches of the Anadyr River and the localities of plant and mollusk fossils (modified from Herman, 2011).

eva, 2010). Since taphoflora of the Grebenka stage occurring in the basin of the Grebenka River was dated not only to the Cenomanian but also, probably, to the latest Albian (Herman, 2011; Shczepetov et al., 1992; Spicer et al., 2002), the beginning of this stage should probably be assigned to the late Albian. Fossil marine mollusks of the Turonian found in the Dugovskaya Formation overlying the Krivorechenskaya Formation (Figs. 1, 2; Terekhova, 1988) made it possible to define the border between the Grebenka and Penzhina stages of flora evolution at the beginning of the Turonian or between the early and late Turonian. However, the change of taphofloras belonging to these two consecutive stages has never been reported in a single stratigraphic section.

Geologists from NPO Aerogeologiya collected fossil plants from the deposits attributed to the Krivorechenskaya Formation in the basin of the Chineiveem River (left bank of the Anadyr River), which were later studied by E.L. Lebedev (Dvoryankin et al., 1993). In his opinion, this taphoflora was fundamentally different in composition from the Grebenka flora and could be conditionally dated to the Senonian. It was because of this that Dvoryankin and his coauthors believed that plant fossils came from a tectonic block not related to the Krivorechenskaya Formation. Later on, Herman (2011), having analyzed the list of plants of the Chineiveem taphoflora given by Lebedev and having reviewed the collection of plant fossils, did not agree with the conclusions of Dvoryankin et al. (1993). The taphoflora, however, has not been studied in sufficient detail to make the conclusions about its age made either by Lebedev or Herman sufficiently substantiated.

In this article, we intend to fill this gap and try to answer the following questions.

(1) What is the taxonomic composition and age of the Chineiveem floristic assemblage? 


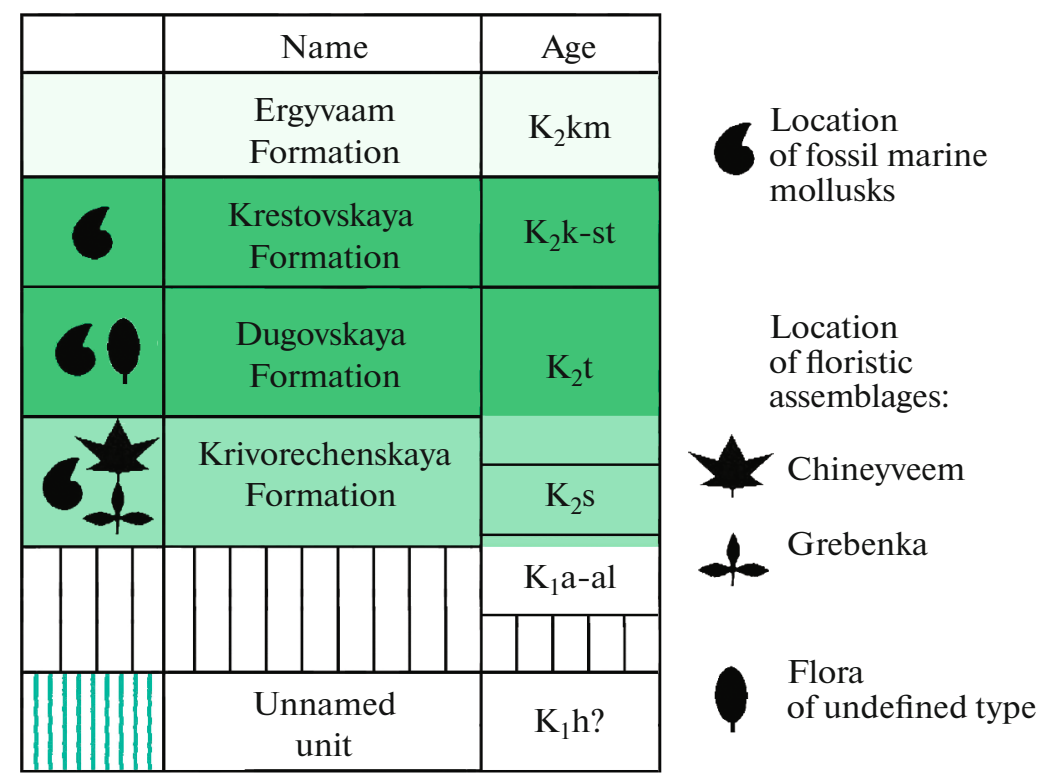

Fig. 2. Sequence of stratified geological bodies on the left bank of the Chineiveem River in the area of the Bolotnyi Stream based on materials by Trunov (Gosudarstvenaya..., 1977).

(2) How justifiable is the opinion on the tectonic contact of plant-bearing layers of the Chineiveem assemblage, with the Dugovskaya Formation of marine genesis?

(3) What is the upper age limit for the Grebenka flora and, accordingly, the Grebenka evolutionary stage of the Cretaceous flora of the Anadyr-Koryak subregion?

\section{STRATIGRAPHY OF THE UPPER CRETACEOUS DEPOSITS \\ OF THE LEFT BANK OF THE ANADYR RIVER (KRIVORECHENSKAYA AND DUGOVSKAYA FORMATIONS)}

The Krivorechenskaya Formation is widespread on the left bank of the Anadyr River in the basins of the Nichekveem, Ubiyenka, Krestovaya, and Chineiveem rivers (Fig. 1). The stratotype of the Krivorechenskaya Formation was identified in 1963 by G.G. Kaigorodtsev on the Krivaya River (right tributary of the Ubiyenka River).

In this area, as well as on the right bank of the Anadyr River (Devyatilova et al., 1980; Filippova and Abramova, 1993; Herman, 2011), the Krivorechenskaya Formation consists of two subformations: the lower, composed essentially of conglomerate, and the upper, composed of conglomerates, gravel conglomerates, polymictic and volcanomictic sandstones, and clayey siltstones. The upper subformation contains numerous plant fossils; however, they are less diverse and poorly preserved than those found on the right bank of the Anadyr River (Filippova and Abramova, 1993). The most representative collections of plant fossils from the Upper Krivorechenskaya Subforma- tion in the basins of the Nichekveem, Ubiyenka, Krivaya, and Dugovaya rivers were made by Devyatilova, Nevretdinov, and Ankudinov and studied by Filippova (1979, 1982, 1984; Filippova and Abramova, 1993; Devyatilova et al., 1980). Fossils Inoceramus cf. nipponicus Nagao et Mat., I. korjakensis Ter., I. ex gr. korjakensis Ter., and I. cf. gradilis Perg. found by Ankudinov in the Upper Krivorechenskaya Subformation on the Levyi Nichekveem River (Fig. 1) suggest, according to Terekhova (1988), that the host sediments belong to the Inoceramus nipponicus Zone of middle to late Cenomanian and, possibly, early Turonian. The thickness of the Krivorechenskaya Formation in this area is about $1600 \mathrm{~m}$.

According to the determinations by Filippova (Filippova and Abramova, 1993), the deposits of the Krivorechenskaya Formation on the Krivaya, Vetvistaya, and Dugovaya rivers (basin of the Ubiyenka River) contain the following (the determinations given in square brackets are in our opinion more correct): Thallites sp., Osmunda sp., Gleichenites zippei (Corda) Sew., Gleichenites microphylla Philipp., Gleichenites asiatica Philipp., Coniopteris grebencaensis Philipp., Asplenium dicksonianum Heer, Birisia jelisejevii (Krysht.) Philipp., Cladophlebis frigida (Heer) Sew., Cladophlebis ex gr. haiburnensis (L. et H.) Brong., Cladophlebis ubiencaensis Philipp., Arctopteris sp. [Arctopteris penzhinensis E. Lebed.], Pseudocycas hyperborea Krysht. [Cycadites hyperborea (Krysht.) E. Lebed.], Nilssonia serotina Heer, Nilssonia alaskana Hollick, Nilssonia yukonensis Hollick, Ginkgo ex gr. adiantoides (Unger) Heer, Sphenobaiera aff. biloba Pryn. [Sphenobaiera vera Samyl. et Shczep.], Cephalotaxopsis heterophylla Hollick, Cephalotaxopsis intermedia Hollick, Elatocla- 
dus gracillimus (Holl.) Sveshn., Araucarites anadyrensis Krysht., Sequoia reichenbachii (Gein.) Heer, Sequoia fastigata, Sequoia obovata Knowlton [most likely, Elatocladus smittiana (Heer) Seward], Sequoia ambigua Heer [Pagiophyllum triangulare Prynada], Cryptomeria subulata (Heer) Sveshn., Florinia borealis Sveshn. et Budantsev, Podozamites lanceolatus (Lindl. et Hutton) Braun, Pityophyllum nordenskioldii (Heer) Nath. [Pityophyllum ex gr. nordenskioldii (Heer) Nath.], Pityostrobus sp., Pityocladus sp., Magnolia alternans Heer [Magnoliaephyllum alternans (Heer) Seward], Menispermites septentrionalis Hollick, Menispermites marcovoensis Philipp., Ettingshausenia embicola (Vachr.) Herman [Ettingshausenia louravetlanica (Herman et Shczepetov) Herman et Moiseeva], Credneria inordinata Hollick [Arthollia inordinata (Holl.) Herman or, most likely, Ettingshausenia louravetlanica], Leguminosites acuminata Philipp. [Myrtophyllum acuminata (Philipp.) Herman], Scheffleraephyllum venustum (Philipp.) Philipp., Grebenkia kryshtofovichii E. Lebed. [Grebenkia anadyrensis (Krysht.) E. Lebed.], Araliaephyllum devjatilovae Philipp., Celastrophyllum latifolium Font.

Having analyzed the taxonomic composition of the taphofloras of the Krivorechenskaya Formation of the right and left banks of the Anadyr River, Filippova (Filippova and Abramova, 1993, p. 19) noted that "they all constitute a floristic assemblage, the unity of which is due to the commonality of the dominant genera and species in the composition of ferns (Gleichenites, Coniopteris, Birisia), conifers (Cephalotaxopsis, Sequoia), and angiosperms (Menispermites, Ettingshausenia, Dalembia), as well as to the presence of ancient mesophytic species". Thus, Filippova attributed the listed fossil plants to the Grebenka flora, and the most representative fossil plant gatherings of this flora were found on the right bank of the Anadyr River (Filippova and Abramova, 1993; Herman, 2011; Shczepetov et al., 1992; Spicer et al., 2002).

The Krivorechenskaya Formation on the left bank of the Anadyr River is conformably overlain by marine sediments of the 600-m-thick Dugovskaya Formation (Fig. 1, 2), represented by sandstones, siltstones, mudstones, and tuffites of various compositions (Paraketsov et al., 1974; Resheniya..., 1982; Terekhova, 1988; Terekhova and Dundo, 1987; Vereshchagin and Terekhova, 1960). These rocks contain fossil marine mollusks, studied by Terekhova (1988): Inoceramus concentricus costatus Nagao et Mat., I. iburiensis Nagao et Mat., I. gibberosus Bodul., I. hobetsensis Nagao et Mat., Scaphites (Otoscaphites) puerculus teshioensis (Yabe), S. (O. ) aff. puerculus Jimbo, $S$. (O.) ex gr. puerculus Jimbo, S. planus (Yabe), Scalarites sp. indet. According to Terekhova (1988, p. 110), "the complex of fossil fauna from the Dugovskaya Formation corresponds to the Inoceramus iburiensis Zone and the Jimboiceras planulatiforme Zone of the same age in the Anadyr-Koryak region," supposedly of late Turonian age (Resheniya..., 1982); "the lowest stratigraphic position in the Dugovskaya Formation is occupied by layers with Inoceramus concentricus costatus Nagao et Mat., which up the section ... give way to deposits with Inoceramus iburiensis Nagao et Mat. and I. gibberosus Bodul., and further up the section ... are replaced by rocks with Inoceramus hobetsensis Nagao et Mat. and scaphites." From this perspective, Terekhova (1988, p. 111) "considered the age of the faunistic assemblages of the Dugovskaya Formation to be late Turonian, not excluding the possibility of assigning the lowest horizons containing Inoceramus concentricus costatus to the lower Turonian." At the same time, she noted that "in the Ubiyenka River basin ... the continental deposits of the Krivorechenskaya Formation with the fossil flora are directly overlapped by marine layers with Inoceramus concentricus costatus. To the north, in the Krestovaya and Chineiveem river basins ..., marine sediments with Inoceramus hobetsensis occur above the continental layers."

The latter observation, as well as the late Albianearly Cenomanian mollusks identified by Terekhova (1988) in the upper subformation of the Krivorechenskaya Formation on the Malaya Grebenka River (right bank of the Anadyr River: Shczepetov et al., 1992) and those of middle Cenomanian-(?) early Turonian age found on the Levyi Nichekveem River, enabled her to conclude that the age of the Krivorechenskaya Formation containing plant fossils "varies depending on the age of the overlying marine sediments. The upper age limit varies from late Albian to late Turonian" (Terekhova, 1988, p. 113). The conclusion about the diachronism of the upper boundary of the Krivorechenskaya Formation and its rejuvenation from south to north was also supported by Pokhialainen (1994), who considered the degree of diachronism even more significant, right up to the end of the Coniacian.

The Dugovskaya Formation is conformably overlain by sandstones and siltstones of the Krestovskaya Formation (Fig. 2), which, according to the fossil marine mollusks contained in them, are early Cenomanian (Terekhova, 1988) or Santonian (Pohialainen, 1994) in age.

Dvoryankin, Lebedev, and Filatova (Dvoryankin et al., 1993) had an entirely different view on the boundary of these formations than Terekhova and thought that the entire or almost the entire boundary was tectonic. These authors believed that "the deposits previously ascribed entirely to the Krivorechenskaya Formation ... include tectonic blocks with the Senonian flora" (Dvoryankin et al., 1993: 475). This taphoflora, which they named the Chineiveem floristic assemblage, was found on the right bank of the Chineiveem River between its tributaries, the Bolotnyi Stream and Obil'naya River (Fig. 3), in the upper part of the coarse-clastic terrigenous strata attributed to the Krivorechenskaya Formation by Terekhova (1988). According to Dvoryankin et al., these plant-bearing rocks form "a tectonic block about $4 \mathrm{~km}$ wide, bounded 


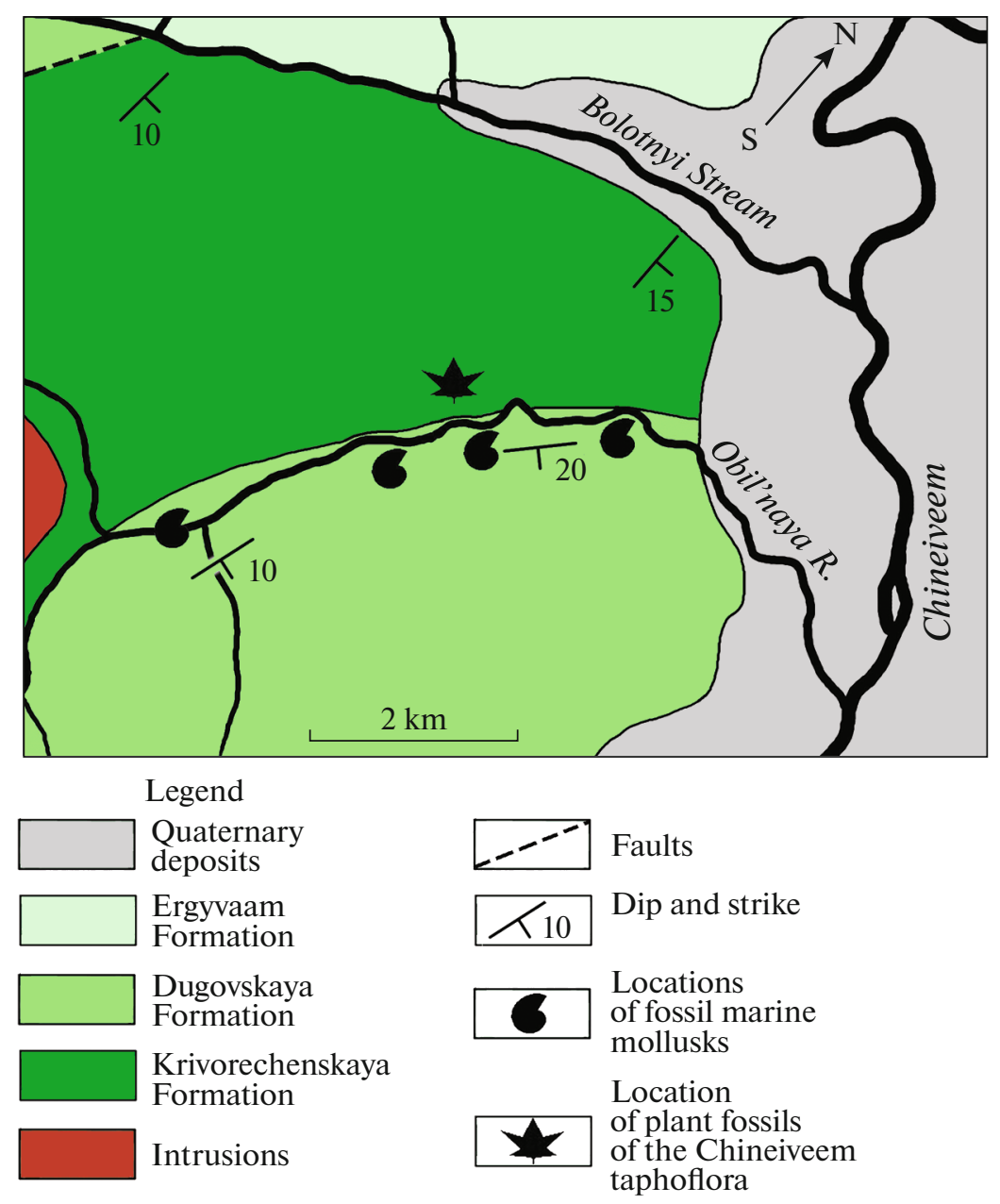

Fig. 3. Schematic geological map of the Chineiveem River basin and the location of fossil marine mollusks and plants (according to GGK-200, sheets Q-59-XXI, XXII, B.D. Trunov, 1972: Gosudarstvenaya..., 1977).

by arcuate faults" (Dvoryankin et al., 1993, p. 473). However, the geologist of NPO Aerogeology V.L. Samsonenko, who took part in field work and collecting Chineiveem taphoflora, claimed (personal communication, 2011) that these tectonic contacts were not possible to observe in the field because of the poor exposure of the area covered by tundra vegetation. Presumably, these faults were established by Dvoryankin et al. by means of interpretation of aerial photographs.

The southeastern margin of the terrigenous unit containing the Chineiveem taphoflora, borders along the fault (according to Dvoryankin et al.) with the deposits attributed to the Dugovskaya Formation by
Terekhova (1988), where during a medium-scale geological survey, Trunov collected Inoceramus cf. hobetsensis Nagao et Mat., Inoceramus sp. indet. (possibly similar to I. iburiensis Nagao et Mat.), Pholadomya sp. indet., and Parallelodon cf. sachalinensis Schmidt., characteristic of the late Turonian; however, "the tectonic nature of the contact between plant-bearing deposits and the layers with the Turonian inocerams does not allow the age of the strata containing the Chineiveem floral assemblage to be corrected according to the aforementioned paleontological data" (Dvoryankin et al., 1993, p. 474).

Lebedev determined the age of the Chineiveem taphoflora by its systematic composition. He noted its

Plate I. Ginkgoaleans, conifers, and angiosperms of the Chineiveem plant assemblage; left bank of the Anadyr River, Chineiveem River basin; Krivorechenskaya Formation, Upper Cretaceous, Turonian. Length of the scale bar is $1 \mathrm{~cm}$. (1) Ginkgo ex gr. adiantoides (Unger) Heer, Sample 5003/65; (2, 3) Sequoia sp., cone: (2) Sample 5003/70, (3) Sample 5003/1-2; (4) Pityostrobus (?) sp., Sample 5003/3; (5, 6) Sequoia rigida Heer: (5) Sample 5003/51, (6) Sample 5003/53; (7, 8) Cephalotaxopsis intermedia Hollick: (7) Sample 5003/2-2, (8) Sample 5003/2-1; (9, 10) Metasequoia cuneata (Newberry) Chaney: (9) Sample 5003/5, (10) Sample 5003/25-1; (11) Araliaephyllum cf. armanensis Herman, lobe of the trilobed leaf, Sample 5003/10. 


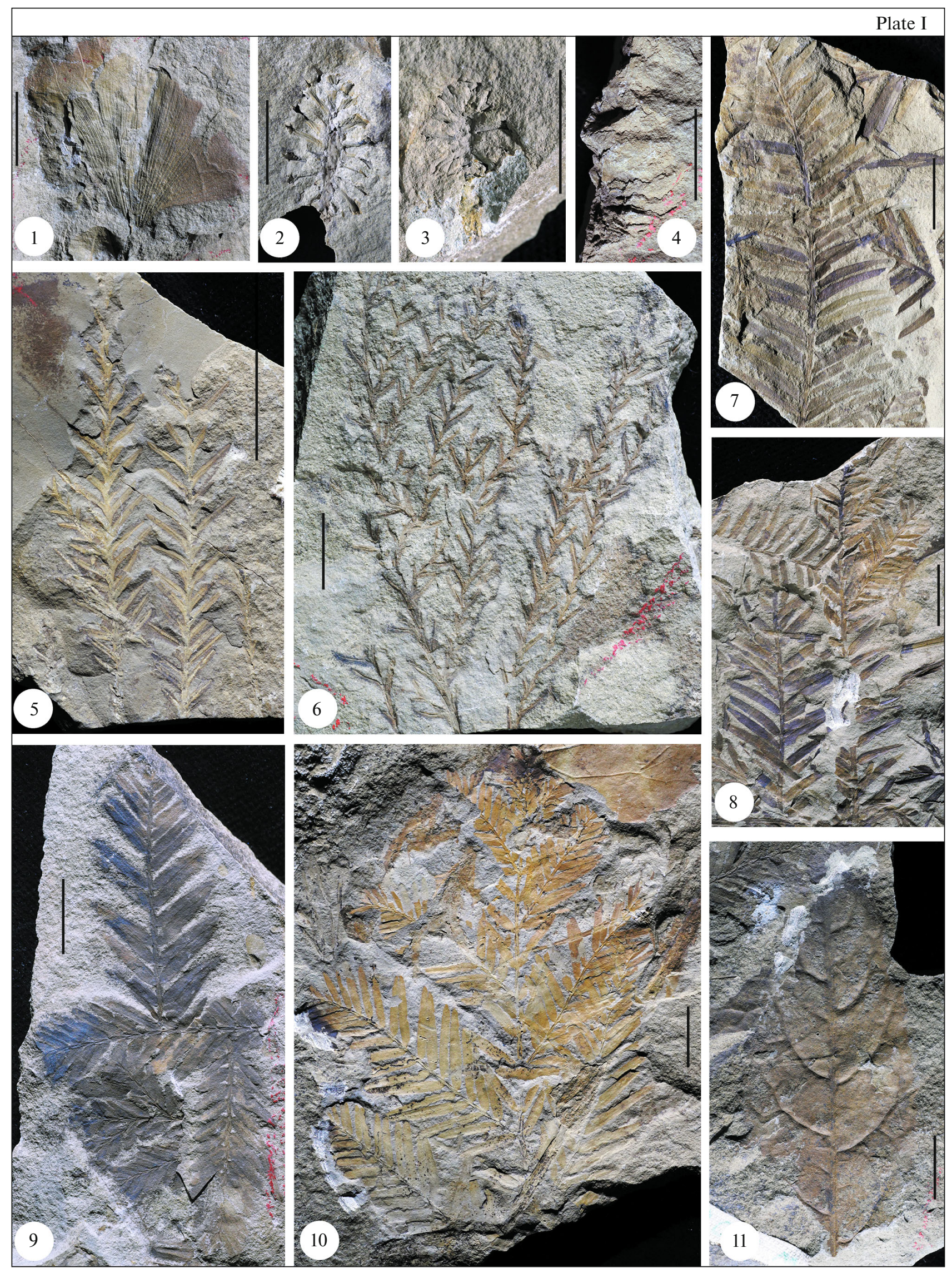


younger appearance in comparison with that of the Grebenka flora (due to the presence of numerous Metasequoia, Trochodendroides, and Arthollia) and a similarity to the Penzhina taphoflora of northwestern Kamchatka. On the basis of the presence of "fossil leaves of the Fagaceae family, belonging either to Quercus or to a new genus" in the Chineiveem assemblage, Lebedev concluded that this flora is "undoubtedly younger than the floras of the Penzhina ... type (late Turonian-Coniacian)" (Dvoryankin et al., 1993, pp. 474-475) and attributed it to the Senonian. The authors cited considered the Senonian Krestovskaya Formation to be a stratigraphic analog of the sequence containing the Chineiveem taphoflora (Fig. 2).

\section{MATERIALS AND METHODS}

The collection examined in this study was collected by Dvoryankin and colleagues when mapping a section of the right bank of the Chineiveem River on the left bank of the Anadyr River (Fig. 3). It includes 81 samples with plant imprints and field mark W1306. Some samples are accompanied by handwritten labels with the determinations made by Lebedev. The material is represented by imprints of leaves, leafy shoots, and reproductive organs (cones); phytoleimmas have not been preserved. This collection is permanently stored in the Geological Institute (GIN), Russian Academy of Sciences, Moscow, collection no. 5003.

Plant fossils after cleaning were studied using a forehead binocular eye loupe or a Carl Zeiss SM-XX dissecting microscope and photographed using a Panasonic Lumix DMC-GX9 digital camera equipped with a Leica DG Macro-Elmarit $1: 2.8 / 45 \mathrm{~mm}$ macro lens.

\section{SYSTEMATIC COMPOSITION AND AGE OF THE CHINEIVEEM TAPHOFLORA}

The Chineiveem floristic assemblage, named after its location (in the basin of the Chineiveem River, Fig. 3), is represented by 23 species of ginkgoaleans, conifers, and angiosperms. It contains the following plants.

\section{Ginkgoales:}

Ginkgo ex gr. adiantoides (Unger) Heer (Plate I, fig. 1);

\section{Pinales:}

Cephalotaxopsis intermedia Hollick (Plate I, figs. 7, 8), Sequoia rigida Heer (Plate I, figs. 5, 6),
Metasequoia cuneata (Newberry) Chaney (Plate I, figs. 9, 10),

Sequoia sp. (cone) (Plate I, figs. 2, 3),

Pityostrobus (?) sp. (Plate I, fig. 4);

Magnoliopsida:

Araliaephyllum cf. armanensis Herman (Plate I, fig. 11),

Magnoliaephyllum ex gr. alternans (Heer) Seward (Plate II, fig. 3),

Cissites cf. inscissus Herman (Plate II, fig. 1),

Myrtophyllum (?) sp. (Plate II, fig. 5),

Menispermites orientalis Golovneva (Plate II, fig. 6),

Menispermites sibiricus (Heer) Golovneva (Plate II, fig. 2),

Trochodendroides ex gr. arctica (Heer) Berry (Plate II, fig. 9, 10),

Arthollia inordinata (Hollick) Herman (Plate III, fig. 1),

Arthollia pacifica Herman (Plate IV, fig. 3),

Ettingshausenia louravetlanica (Herman et Shczepetov) Herman et Moiseeva (Plate IV, figs. 1, 2), Ettingshausenia primaeva (Lesquereux) Herman (Plate III, figs. 2, 3),

platanoid reproductive structures (Plate III, fig. 4; Plate IV, figs. 4, 5),

Celastrophyllum orientalis Philippova (Plate IV, fig. 7),

Viburniphyllum whymperi (Heer) Herman (Plate IV, fig. 8),

Grebenkia cf. anadyrensis (Kryshtofovich) E. Lebedev (Plate II, figs. 7, 8),

Parvileguminophyllum (?) sp. (Plate II, fig. 4),

Chachlovia dombeyopsoida (Herman) Herman (Plate IV, fig. 6).

There are no bryophyta, ferns, leptostrobaleans, cycadaleans, bennettitaleans, or caytonialeans in the Chineiveem taphoflora. Ginkgoaleans are represented by a single fragmentary imprint of Ginkgo ex gr. adiantoides. Conifers are numerous, the most common are leafy shoots of Sequoia rigida and Metasequoia cuneata, and less common are shoots of Cephalotaxopsis intermedia. The reproductive organs of conifers are represented by isolated finds of fossil taxodiaceous and, possibly, pinaceous cones. Angiosperms are the most abundant and diverse in terms of the number of imprints, including 17 species from 14 genera, the most frequent of them being Cissites cf. inscissus, Trochodendroides ex gr. arctica, Viburniphyllum whymperi, and platanoids, rep-

Plate II. Angiosperms of the Cineiveem plant assemblage; left bank of the Anadyr River, Chineiveem River basin; Krivorechenskaya Formation, Upper Cretaceous, Turonian. Length of the scale bar is $1 \mathrm{~cm}$. (1) Cissites cf. inscissus Herman, Sample 5003/61; (2) Menispermites sibiricus (Heer) Golovneva, Sample 5003/68; (3) Magnoliaephyllum ex gr. alternans (Heer) Seward, Sample 5003/57-2; (4) Parvileguminophyllum (?) sp., Sample 5003/22-1; (5) Myrtophyllum (?) sp., Sample 5003/50-2; (6) Menispermites orientalis Golovneva, Sample 5003/23; (7, 8) Grebenkia cf. anadyrensis (Kryshtofovich) E. Lebedev: (7) Sample 5003/50-1, (8) Sample 5003/35-1; (9, 10) Trochodendroides ex gr. arctica (Heer) Berry: (9) Sample 5003/59, (10) Sample 5003/77. 


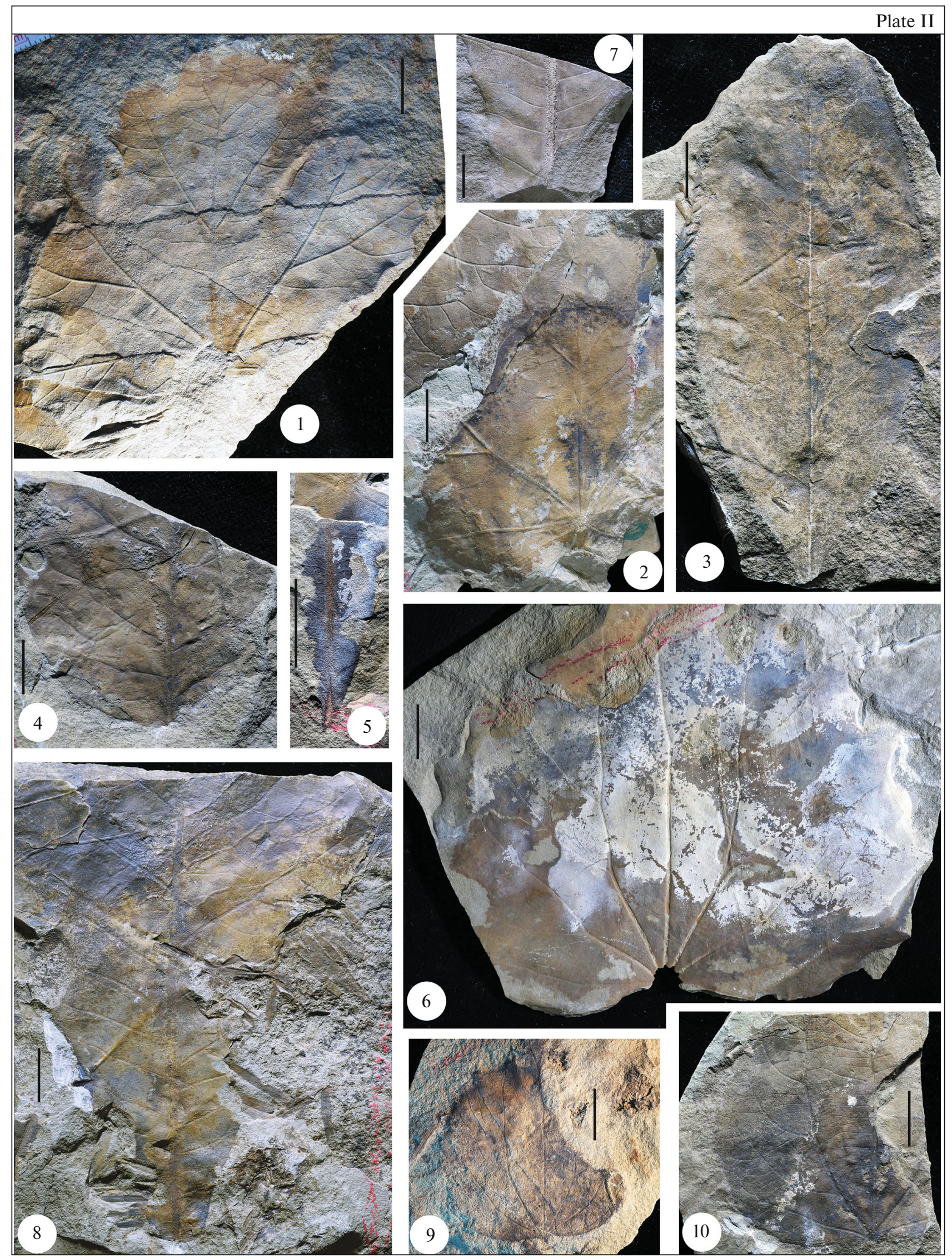


resented by the fossil leaves of Arthollia inordinata, A. pacifica, Ettingshausenia louravetlanica, and E. primaeva, as well as the only find of an imprint of a platanoid reproductive organ, sessile capitate structure. According to N.P. Maslova (personal communication, 2020), their preservation is insufficient to accurately determine whether they are infructescences or male inflorescences. It cannot be ruled out that these capitate structures are close or identical to the complex infructescences of Anadyricarpa altingiosimila N. Maslova et Herman from the Krivorechenskaya Formation on the Grebenka River (right bank of the Anadyr River), which were associated with fossil leaves of Ettingshausenia louravetlanica (Maslova and Herman, 2004). The rest of the fossil angiosperm finds were scarce and sporadic.

As was mentioned above, Devyatilova and Terekhova (Devyatilova et al., 1980; Terekhova, 1988) believed that the Chineiveem taphoflora comes from the top of the Krivorechenskaya Formation, which is also associated with numerous finds of fossil plants of the rich and diverse Grebenka flora (Filippova and Abramova, 1993; Herman, 2011, 2013; Shczepetov et al., 1992; Spicer et al., 2002). The Chineiveem assemblage shows a certain similarity to this flora, which includes a number of species that are identical or close to the Chineiveem species: Ginkgo ex gr. adiantoides, Cephalotaxopsis intermedia, Magnoliaephyllum alternans, Menispermites ex gr. sibiricus, Ettingshausenia louravetlanica, Arthollia cf. pacifica, Trochodendroides ex gr. arctica, Cissites cf. inscissus, Grebenkia anadyrensis. The difference between these floras, however, is significant: such dominants of the Chineyveem taphoflora as the conifers Metasequoia are entirely absent in the Grebenka flora, and finds of the angiosperms Trochodendroides, Ettingshausenia, and Arthollia are isolated or relatively rare. These plants, however, become common and, as a rule, abundant in the floras of Northeast Asia that are younger than Grebenka flora. Conversely, many characteristic plants of the Grebenka flora are absent in the Chineiveem flora. It is also significant that the angiosperms leaves with an entire margin are very rare in the Chineiveem flora, while they constitute a substantial part of the Grebenka flora. The Chineiveem taphoflora includes plants known from the Turonian and younger floras of the region: Metasequoia cuneata, Araliaephyllum cf. armanensis, Arthollia inordinata, Celastrophyllum orientalis, Viburniphyllum whymperi, Chachlovia dombeyopsoida. Note that the large-leaved platanoids, the greatest abundance of which in Northeast Asia occurred during the Turonian (Herman, 2011), are predominant in the Chineiveem taphoflora (four spe- cies from two genera). The distinctive feature of the Chineiveem flora is the absence of ferns, cycadaleans, bennettitaleans, and caytonialeans, which are usually found in the Cretaceous floras of Northeast Asia.

In our opinion, the Chineiveem taphoflora is undoubtedly younger than the Grebenka flora and is closest to the Penzhina taphoflora of Northwestern Kamchatka and the Yelistratov Peninsula, which are securely dated as Turonian, excluding the beginning of the Turonian (Herman, 2011, 2013; Herman and Lebedev, 1991). The similar age of the Penzhina and Chineveyem floras is evidenced by (1) similar species (Cephalotaxopsis intermedia, Metasequoia cuneata, Magnoliaephyllum ex gr. Alternans, Cissites cf. inscissus, Menispermites sibiricus, M. orientalis, Trochodendroides ex gr. pacifica, Ettingshausenia primaeva, Viburniphyllum whymperi, Grebenkia cf. anadyrensis) and genera (Sequoia, Pityostrobus, Araliaephyllum, Myrtophyllum, Celastrophyllum) present in both; (2) the abundance of plants of the genera Metasequoia, Trochodendroides, and Menispermites; and (3) significant diversity and quantitative predominance of largeleaved platanoid angiosperms.

The conclusion of Lebedev about the Senonian age of the Chineveyem assemblage (Dvoryankin et al., 1993) is based mainly on the presence of leaves attributed to Fagophyllum sp. (gen. nov.?) of the modern Fagaceae family. This definition, however, appears to be erroneous, since the few fragmentary poorly preserved imprints of these leaves, in our opinion, are similar to the Grebenka species Grebenkia anadyrensis and only differ from it in the larger size of the leaf blade. It should be noted that Lebedev himself most likely doubted the definition of Fagophyllum sp. (gen. nov.?): on the some labels for these imprints, the note "Grebenkia (?)" is written in his hand. All this allows the Chineiveem taphoflora to be considered approximately the same age as the Penzhina taphoflora and date it to the Turonian, most likely to the late Turonian.

The Chineiveem taphoflora reveals a certain similarity with the floristic assemblages of the next, Kaivayam, stage of the flora evolution in the AnadyrKoryak subregion. This stage is represented by the Kaivayam assemblage of Northwest Kamchatka and the Yelistratov Peninsula, the Poperechnaya assemblage of the eastern slope of the Pekulney Ridge, and the Tylpegyrgynai assemblage of the western slope of the Pekulney Ridge (Craggs, 2005; Filippova, 2010; Herman, 2011, 2013; Herman and Lebedev, 1991). The deposits containing the fossil plants of these assemblages are reliably dated to the Coniacian (Kaivayam assemblage) or to the early Coniacian (Poperechnaya

Plate III. Angiosperms of the Chineiveem plant assemblage; left bank of the Anadyr River, Chineiveem River basin; Krivorechenskaya Formation, Upper Cretaceous, Turonian. Length of the scale bar is $1 \mathrm{~cm}$. (1) Arthollia inordinata (Hollick) Herman, Sample 5003/18; (2, 3) Ettingshausenia primaeva (Lesquereux) Herman: (2) Sample 5003/73, (3) Sample 5003/8; (4) platanoid reproductive structure, Sample 5003/26. 


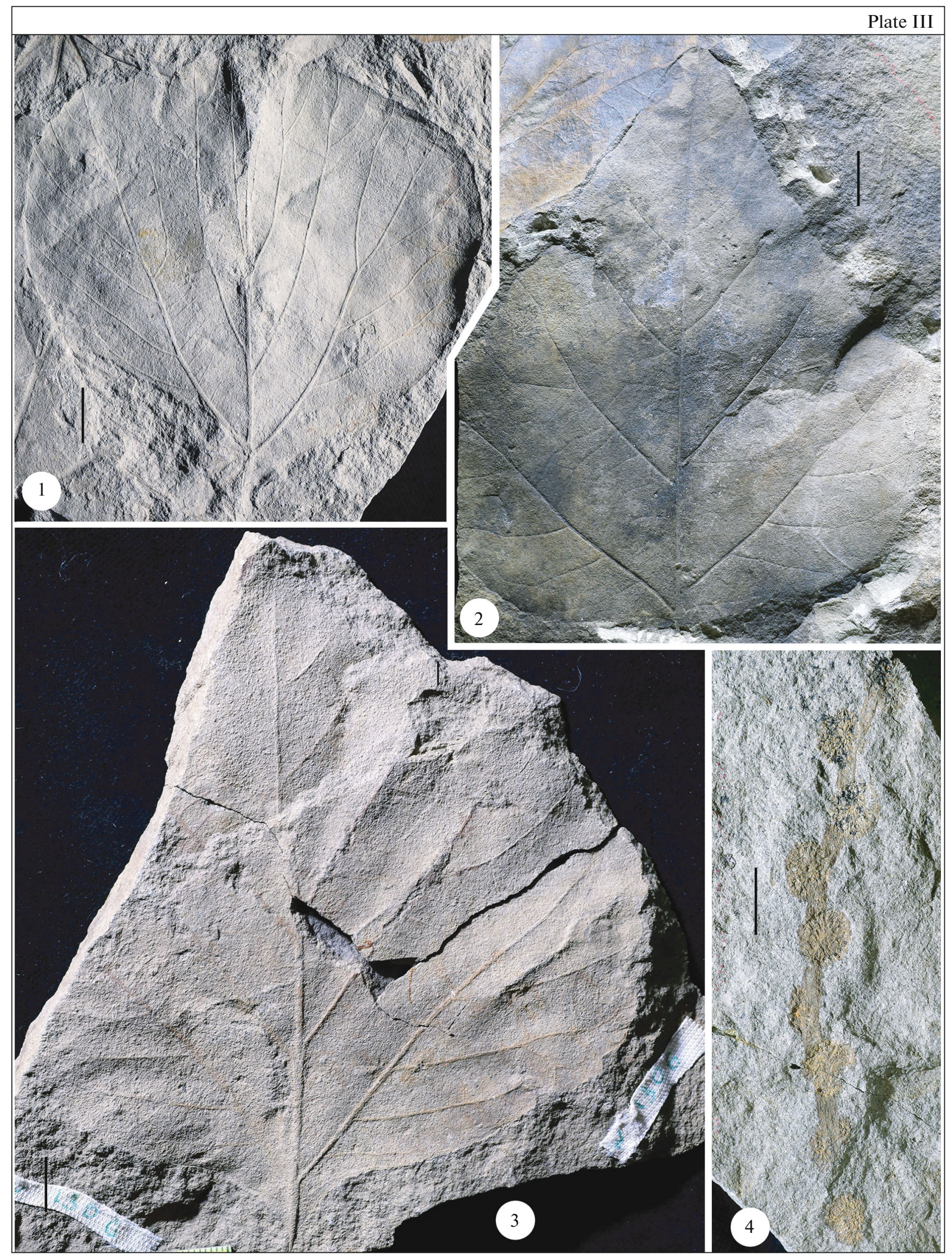




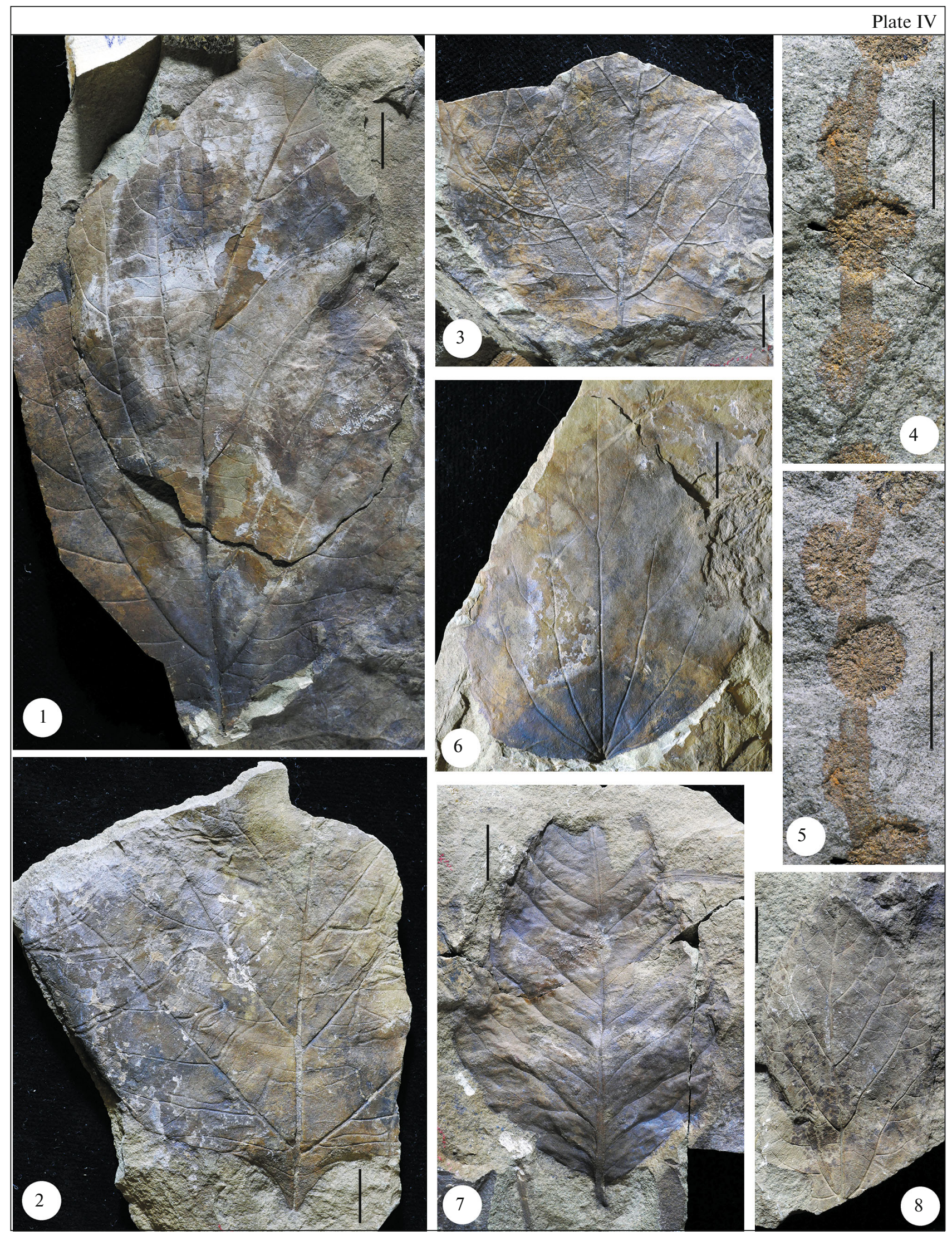


Plate IV. Angiosperms of the Chineiveem plant assemblage; left bank of the Anadyr River, Chineiveem River basin; Krivorechenskaya Formation, Upper Cretaceous, Turonian. Length of the scale bar is $1 \mathrm{~cm} .(1,2)$ Ettingshausenia louravetlanica (Herman et Shczepetov) Herman et Moiseeva: (1) Sample 5003/79, (2) Sample 5003/27; (3) Arthollia pacifica Herman, Sample 5003/67; $(4,5)$ platanoid reproductive structure, Sample 5003/26; (6) Chachlovia dombeyopsoida (Herman) Herman, Sample 5003/30; (7) Celastrophyllum orientalis Philippova, Sample 5003/78; (8) Viburniphyllum whymperi (Heer) Herman, Sample 5003/43.

and Tylpegyrgynai assemblages) due to their interfingering with marine layers containing the fossil mollusks. These floristic assemblages, as well as the Chineiveem taphoflora, are characterized by a significant amount of conifers Metasequoia and angiosperms Trochodendroides, as well as large-leaved platanoids. At the same time, they have fewer species in common with the Chineiveem taphopholora than the Penzhina flora: only Ginkgo ex gr. adiantoides, Cephalotaxopsis intermedia, Metasequoia cuneata, Magnoliaephyllum alternans, Menispermites sibiricus, Arthollia pacifica, Cissites inscissus, Viburniphyllum whymperi, and Chachlovia dombeyopsoida. Thus, the age of the Chineiveem taphoflora appears to be older than the Coniacian.

\section{CONCLUSIONS}

Answering the questions formulated in the introduction to this article, we can state the following.

(1) The Chineiveem taphoflora is characterized by a low variety of plants, represented by ginkgoaleans, conifers, and angiosperms. Judging by their composition, it is younger than the Grebenka flora and similar to the Penzhina flora of Northwestern Kamchatka and the Yelistratov Peninsula. Therefore, we believe that the Chineyveem taphoflora is approximately the same age as the Penzhina taphoflora and has Turonian age, most likely late Turonian.

It should be noted that, as was pointed out by Belyi (personal communication, 1998), on the left bank of the Chineiveem River, north of the Chineiveem taphoflora section, continental facies with plant fossils appear in the Dugovskaya Formation, which contains abundant fossil fauna of the late Turonian (Fig. 3). According to Belyi, it cannot be ruled out that the very location of the Chineiveem taphoflora belongs to the Dugovskaya Formation instead of the Krivorechenskaya Formation, as was presumed by Terekhova.

(2) There are two mutually exclusive points of view on the relationship of the Krivorechenskaya and Dugovskaya formations on the left bank of the Anadyr River: (a) their contact is gradual, conformable without traces of interruption (Terekhova, 1988; personal communication, 1983; Fig. 3); (b) the contact between the formations in this area is tectonic (Dvoryankin et al., 1993). Examination of the Chineyveem taphoflora fossil plant collection made us support the first point of view. As shown on the map by Trunov (Gosudarstvennaya..., 1977), the locality of the Chineiveem plant assemblage is located in the uppermost part of the section of the Krivorechenskaya Formation near the base of the Dugovskaya Formation.
Our conclusion about the Turonian (most probably, late Turonian) age of the Chineiveem taphoflora is quite consistent with the concept of the late Turonian or Coniacian age of marine mollusks from the overlying layers of the Dugovskaya Formation on the Chineiveem River (Pohialainen, 1994; Terekhova, 1988) and a conformable stratigraphic contact of these layers with plant-bearing deposits.

It should be noted that our conclusion about the age of the Chineiveem assemblage deprives the point of view of Dvoryankin et al. of its most serious paleobotanical evidence and, perhaps, of its very foundation. It seems quite probable that the idea of a tectonic contact between the two formations appeared in view of the need to separate the "younger" plant-bearing deposits from the "older" marine layers with the fossil mollusks. As was noted above, Samsonenko, who took part in field work on the Chineiveem River, did not observe this fault. After the publication of the article by Dvoryankin et al. (1993), Shczepetov analyzed all published and archive materials on the area described, deciphered aerial photographs, and found no evidence of tectonic faults separating the deposits with the Chineiveem taphoflora from the Krivorechenskaya and Dugovskaya formations. These faults were also not identified by Belyi, a recognized specialist of deciphering aerial photographs (Belyi and Belaya, 1998, Fig. 4).

(3) The above data on the relationship of the plantbearing layers of the Krivorechenskaya Formation on the left bank of the Anadyr River to overlying marine sediments and the composition of floristic assemblages make it possible, in our opinion, to consider taphofloras from the Ubiyenka, Krivaya, and Dugovaya rivers as an analog of the conventional Grebenka flora on the right bank of the Anadyr River and date them to the Cenomanian and, possibly, to the early Turonian. The Chineiveem taphoflora of the upper part of the Krivorechenskaya Formation, on the other hand, should be distinguished from the Grebenka flora and attributed, most likely, to the late Turonian. In other words, the sequence of taphofloras from the Krivorechenskaya Formation in the UbiyenkaChinevei interfluve allows the upper age limit of the distribution of the Grebenka flora to be constrained by the beginning of the Turonian. Consequently, the left bank of the Anadyr River is interesting, first of all, because here one can trace how the taphofloras of the Grebenka stage of the Anadyr-Koryak subregion are replaced by those of the Penzhina stage in a single section. The authors' ideas about the relationship of marine and continental Cretaceous deposits of the middle reaches of the Anadyr River, containing the Grebenka and Chineiveem flora, are shown in Fig. 4. 


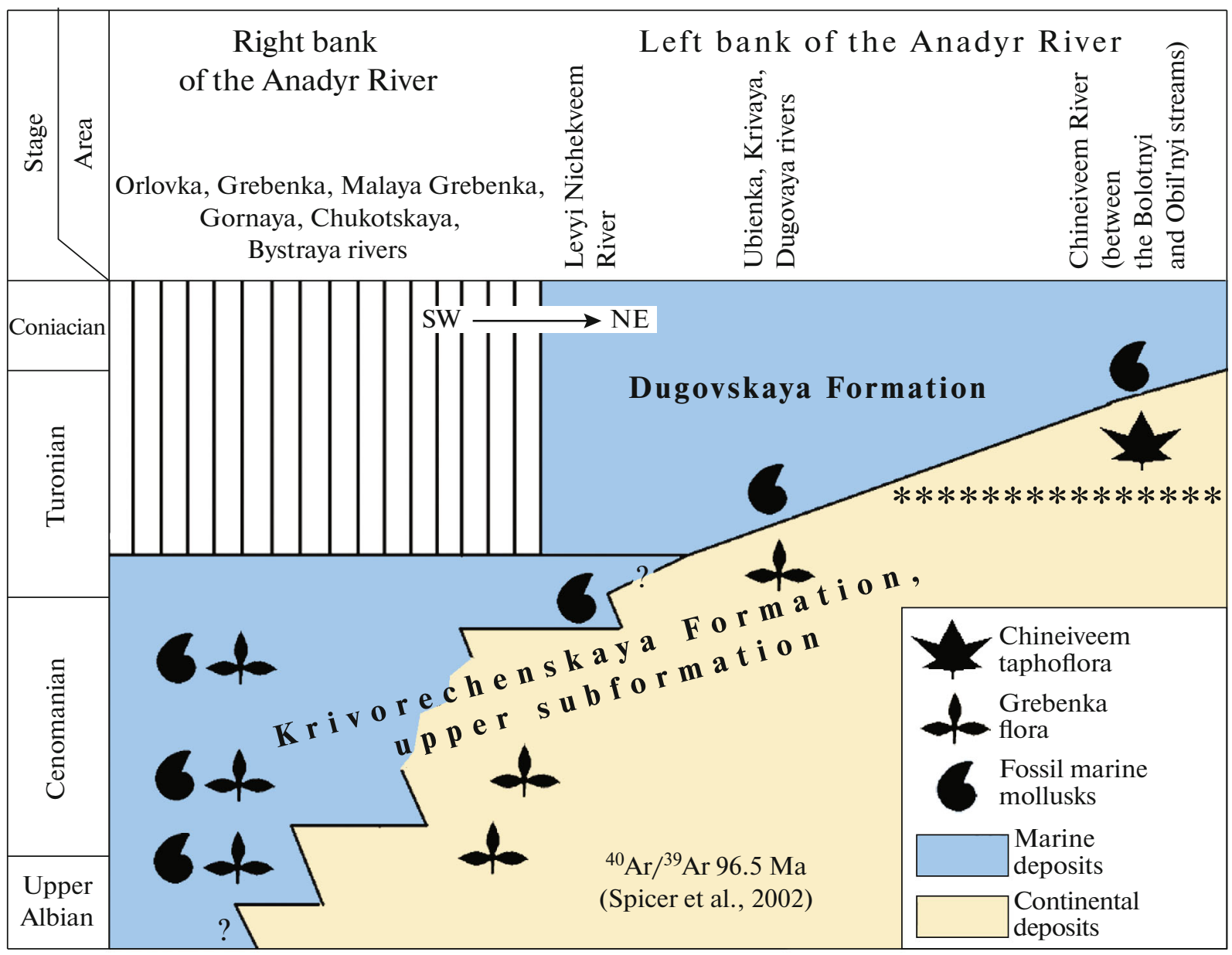

Fig. 4. Relationship of continental plant-bearing deposits of the Krivorechenskaya Formation to marine formations in the middle reaches of the Anadyr River; asterisks indicate the estimated upper boundary of the Grebenka flora (modified from Herman, 2011).

\section{ACKNOWLEDGMENTS}

The authors are sincerely grateful to G.P. Terekhova and V.L. Samsonenko for important information on the geology of the left bank of the Anadyr River, to N.P. Maslova (Paleontological Institute, Russian Academy of Sciences, Moscow) for valuable advice on the platanoid reproductive organ, and to B.N. Shurygin (Trofimuk Institute of Petroleum Geology and Geophysics, Siberian Branch, Russian Academy of Sciences, Novosibirsk) and E.V. Bugdaeva (Federal Scientific Center of the East Asia Terrestrial Biodiversity, Far Eastern Branch, Russian Academy of Sciences, Vladivostok), whose comments on the manuscript allowed it to be significantly improved.

\section{FUNDING}

This work was carried out within the framework of the state assignments for the Geological Institute of the Russian Academy of Sciences and the Botanical Institute of the Russian Academy of Sciences and supported by the Russian Foundation for Basic Research, grant no. 19-05-00121.

Reviewers E.V. Bugdaeva, V.A. Zakharov, and B.N. Shurygin

\section{OPEN ACCESS}

This article is licensed under a Creative Commons Attribution 4.0 International License, which permits use, sharing, adaptation, distribution and reproduction in any medium or format, as long as you give appropriate credit to the original author(s) and the source, provide a link to the Creative Commons license, and indicate if changes were made. The images or other third party material in this article are included in the article's Creative Commons license, unless indicated otherwise in a credit line to the material. If material is not included in the article's Creative Commons license and your intended use is not permitted by statutory regulation or exceeds the permitted use, you will need to obtain permission directly from the copyright holder. To view a copy of this license, visit http://creativecommons.org/licenses/by/4.0/.

\section{REFERENCES}

Belyi, V.F. and Belaya, B.V., Pozdnyaya stadiya razvitiya Okhotsko-Chukotskogo vulkanogennogo poyasa (verkhnee techenie r. Enmyvaam) (The Late Stage of the Evolution of the Okhotsk-Chukotka Volcanogenic Belt: Upper Reaches of the Enmyvaam River), Magadan: Sev.-Vost. Kompl. Nauchno-Issled. Inst. Dal'nevost. Otd. Ross. Akad. Nauk, 1998 [in Russian]. 
Craggs, H.J., Late Cretaceous climate signal of the Northern Pekulney Range flora of northeastern Russia, Palaeogeogr., Palaeoclimatol., Palaeoecol., 2005, vol. 217, pp. 25-46.

Devyatilova, A.D., Nevretdinov, E.B., and Filippova, G.G., Stratigraphy of Upper Cretaceous deposits of the Anadyr River middle reaches basin, Geol. Geofiz., 1980, no. 12, pp. 62-70.

Dvoryankin, A.I., Lebedev, E.L., and Filatova, N.I., The Cenonian Chineiveem floral assemblage in the northeastern Russia (Anadyr River right bank) and its geological significance, Dokl. Akad. Nauk, 1993, vol. 333, no. 4, pp. 473-476.

Filippova, G.G., Cenomanian flora of the Grebenka River and its significance for stratigraphy, in Dal'nevostochnaya paleofloristika. Tr. Biol-pochv. Inst. DVNTS AN SSSR. Nov. Ser. T. 53 (156) (The Far Eastern Paleofloristics. Trans Inst. Biol. Soil Sci. FEB RAS USSR Acad. Sci. New Ser. Vol. 53(156)), Vladivostok: Dalnevost. Nauchn. Tsentr Akad Nauk SSSR, 1979, pp. 91-115.

Filippova, G.G., New Cretaceous angiosperms from the middle reaches of the Anadyr River basin, Materialy po geologii i poleznym iskopaemym Severo-Vostoka SSSR (Materials on Geology and Mineral Resources of Northeastern Russia), Magadan: Sevvostokgeologiya, 1982, vol. 26, pp. 69-75.

Filippova, G.G., Cretaceous conifers from the Anadyr River middle reaches, in Stratigrafiya i paleontologiya paleozoiskikh $i$ mezozoiskikh otlozhenii Severo-Vostoka SSSR (Stratigraphy and paleontology of Paleozoic and Mesozoic Deposits of Northeastern Russia), Moscow: Geol. Fond RSFSR, 1984, pp. 154-174.

Filippova, G.G., Stratigrafiya i flora melovykh otlozhenii severnoi chasti khrebta Pekul'nei (Chukotka) (Stratigraphy and Flora of the Cretaceous Deposits in the Northern Pekul'nei Ridge (Chukotka)), Magadan: Sev.-Vost. Kompl. Nauchno-Issled. Inst. Dalnevost. Otd. Ross. Akad. Nauk, 2010 [in Russian].

Filippova, G.G. and Abramova, L.N., Pozdnemelovaya flora Severo-Vostoka Rossii (Late Cretaceous Flora of Northeastern Russia), Moscow: Nedra, 1993 [in Russian].

Herman, A.B., Albian-Paleocene flora of Northern Pacific, in Tr. Geol. Inst. RAN. Vyp. 592 (Proc. Geol. Inst. Ross. Acad. Sci. Vol. 592), Moscow: GEOS, 2011 [in Russian].

Herman, A.B., Stages and cycles in the Late Cretaceous floral changes of the Anadyr'-Koryak subregion (Northeast Russia) and their connection with climatic changes, Stratigr. Geol. Correl., 1993, vol. 1, no. 1, pp. 77-87.

Herman, A.B. and Lebedev, E.L., Stratigraphy and flora of the Cretaceous deposits of the Northwestern Kamchatka, in Tr. Geol. Inst. Akad. Nauk SSSR. Vyp. 468 (Trans. Geol. Inst. USSR Acad. Sci. Vol. 468), Moscow: Nauka, 1991.

Herman, A.B., Albian-Paleocene flora of the North Pacific: systematic composition, palaeofloristics and phytostratigraphy, Stratigr. Geol. Correl., 2013, vol. 21, no. 7, pp. 689-747. Gosudarstvennaya geologicheskaya karta SSSR masshtaba 1:200000. Seriya Anadyrskaya. List Q-59-XXI, XXII. Ob"yasnitel'naya zapiska (The 1 : 200000 State Geological Map of the USSR. Ser. Anadyr. Sheet Q-59-XXI, XXII. Explanatory Note), Magadan, 1977 [in Russian]

Maslova, N.P. and Herman, A.B., New finds of fossil hamamelids and data on the phylogenetic relationships between the Platanaceae and Hamamelidaceae, Paleontol. J., 2004, no. 5, pp. 563-575.

Moiseeva, M.G., New data on the Cenomanian Flora of the Ugol'naya bay (Northeastern Russia), Paleontol. J., 2010, no. 2, pp. 100-110.
Paraketsov, K.V., Pokhialainen, V.P., and Terekhova, G.P., Biostratigraphic subdivision of Cretaceous deposits of the Anadyr-Koryak region, in Osnovnye problemy biostratigrafii i paleogeografii Severo-Vostoka SSSR. Ch. 2. Mezozoi. Tr. SVKNII DVNTS AN SSSR. Vyp. 63 (The Basic Problems of Biostratigraphy and Paleogeography of the Northeastern USSR. Pt. 2: Mesozoic. Trans. Shilo North-East Interdisciplinary Sci. Res. Inst. FEB RAS), Vladivostok: Dalnevost. Tsentr Akad. Nauk SSSR, 1974, pp. 196-227.

Pokhialainen, V.P., Mel Severo-Vostoka Rossii (Cretaceous of Northeastern Russia), Magadan: Sev.-Vost. Kompl. Nauchno-Issled. Inst. Dal'nevost. Otd. Ross. Akad. Nauk, 1994 [in Russian].

Resheniya 2-go Mezhvedomstvennogo stratigraficheskogo soveshchaniya po melu, paleogenu i neogenu Koryakskogo nagor'ya, Kamchatki, Komandorskikh ostrovov i Sakhalina (Petropavlovsk-Kamchatskii, 1974) (Resolutions of the 2nd Interdepart. Stratigr. Meet. on Cretaceous, Paleogene, and Neogene of the Koryak Highland, Kamchatka, Komandor Islands, and Sakhalin (Petropavlovsk-Kamchatsky, 1974)), Petropavlovsk-Kamchatsky: Ross. Geogr. O-vo "Kamchatgeologiya”, 1982 [in Russian].

Resheniya Tret'ego Mezhvedomstvennogo regional'nogo stratigraficheskogo soveshchaniya po dokembriyu, paleozoyu $i$ mezozoyu Severo-Vostoka Rossii (Sankt-Peterburg, 2002) (Resolution of the 3rd Interdepartmental Regional Stratigraphic Conferences on Precambrian, Paleozoic, and Mesozoic of Northeastern Russia (St. Petersburg, 2002)), St. Petersburg: Vseross. Nauchno-Issled. Geol. Inst., 2009 [in Russian].

Samylina, V.A., The Early Cretaceous floras of northeastern USSR (to the problem of the formation of Cenophytic floras), in XXVII Komarovskie chteniya (XXVII Komarov's Readings), Leningrad: Nauka, 1974.

Shczepetov, S.V., Herman, A.B., and Belaya, B.V., Srednemelovaya flora pravoberezh'ya reki Anadyr' (stratigraficheskoe polozhenie, sistematicheskii sostav, atlas iskopaemykh rastenii) (Middle Cretaceous Flora on the Right Bank of the Anadyr River: Stratigraphic Range, Taxonomic Composition, and Atlas of Fossil Plants), Magadan: Sev.-Vost. Kompl. Nauchno-Issled. Inst. Dal'nevost. Otd. Akad. Nauk SSSR, 1992 [in Russian].

Spicer, R.A., Ahlberg, A., Herman, A.B., Kelley, S.P., Raikevich, M., and Rees, P.M., Palaeoenvironment and ecology of the middle Cretaceous Grebenka flora of northeastern Asia, Palaeogeogr., Palaeoclimatol., Palaeoecol., 2002, vol. 184, nos. 1-2, pp. 65-105.

Terekhova, G.P., On the age of the Krivorechenskaya Formation and Grebenka floral assemblage, in Stratigrafiya i paleontologiya fanerozoya Severo-Vostoka SSSR (Stratigraphy and Paleontology of the Phanerozoic of Northeastern USSR), Magadan: Sev.-Vost. Kompl. Nauchno-Issled. Inst. Dal'nevost. Otd. Akad. Nauk SSSR, 1988, pp. 100-117.

Terekhova, G.P. and Dundo, O.P., Anadyr-Koryak Region, in Stratigrafiya SSSR. Melovaya sistema (Stratigraphy of the USSR. Cretaceous System), Moscow: Nedra, 1987, semivol. 2, pp. 137-154.

Vereshchagin, V.N. and Terekhova, G.P., Upper Cretaceous marine deposits on the left bank of the Anadyr River, north of the Markovo settlement, in Materialy po geologii $i$ poleznym iskopaemym Severo-Vostoka SSSR (Materials on Geology and Mineral Resources of Northeastern USSR), Magadan: Sevvostokgeologiya, 1960, vol. 14, pp. 198-200.

Transtated by M. Hannibal 